\title{
Inclusion of Perceived Risk with TAM in Measuring Attitude Toward online Banking
}

\author{
Monalisa Salam \\ Assiatnt Professor, Department of Business Adminstration,Stamford University Bangladesh
}

\begin{abstract}
Technology adaption is relatively a costly and has a low success rate in countries like Bangladesh. In 1989, Fred Davis suggested the technology acceptance model (TAM). It examines the mediating role of perceived ease of use and perceived usefulness in their relation between systems characteristics (external variables) and the probability of system use (an indicator of system success).In present study the researcher had concluded that TAM is a useful model, but has to be integrated into a broader one which would include more variables like perceived Risk to the adoption of the innovation model. The hypothesized model was validated empirically using a sample size of 389 users of online banking which reveals that Attitude positively influences the intention to use Internet Banking moreover, Perceived ease of use, Perceived usefulness positively influence the intention and attitude to use Internet Banking on the other hand perceived risk has a negative influence on both.
\end{abstract}

Keywords: TAM, Perceived Usefulness, Perceived Ease of Use, Perceived Risk ,Attitude.

DOI: $10.7176 / \mathrm{EJBM} / 11-2-08$

\section{Introduction}

In recent time Internet has played a vital role in our lives ranging from sending emails to buying goods to availing matrimonial services (Chowdhury\& Salam, 2015).Banking has made even esier than ever before with the help of internet.Internet banking is an internet portal, through which customers can exercise different kinds of banking services ranging from bill payment to making investments (Pikkarainen et al., 2004). They also argued that banks use online banking as it is one of the cheapest and easiest delivery channels for the banking products. Karjaluoto et al. (2002) identifies that banking is no longer bound to time and geography rather customers all over the world have relatively easy access to their accounts, 24 hours per day, and seven days a week because with online banking services, the customers who felt that branch banking took too much time and effort are now able to make transactions at the click of their fingers.

E-banking is now a global phenomenon. It is an invaluable and powerful tool driving development, supporting growth, promoting innovation and enhancing competitiveness (Kamel, 2005 and Nath, Shrick and Parzinger, 2001). Internet Banking is growing popular day by day in Bangladesh. A number of private as well as local banks are going online now considering the demand and necessity of fast banking. Internet banking not only provides banking facility round the clock but also helps a country to get attached to the international economy as well as business. People throughout the world are now getting engaged with more activity and business and hence need the fast and anytime access to his/her bank account.Internet banking also facilitates buying and selling various products which varies country to country.

At present, several private commercial banks (PCBs) and foreign commercial banks (FCBs) in Bangladesh offered limited services of tele banking, internet banking, and online banking facilities working within the branches of individual

bank in a closed network environment. Amongst those HSBC, City Bank, BRAC Bank, Bank Asia, Jamuna Bank, Janata Bank, Southeast Bank, AB Bank, First Security Bank, Mercantile Bank, Premier Bank etc are in action already. Some are known as online banking, some are Internet Banking, providing various facilities. (http://bankinfobd.com/blog/internet-banking-in-bangladesh)As the world economy is growing faster and banking sector is making mark each and every day, online banking is very important and effective to be a part of it. Bangladesh just started its journey in internet banking and banks are coming forward to make it a success. Online banking is clearly a huge benefit for the customers and saves a lot of time and things get done so easily. A developing country like Bangladesh can make the best out of Internet Banking and banks are completely into it.

Banking has never been more important to our society than it is today. The advance of communication and computer technology and the availability of the Internet have made it possible that one can do most banking transactions from a remote location even without

stepping into a physical financial structure - that is, the emerging of e-banking (Bruene, 2002).As this paper aims to investigate the influence of technology readiness on users attitude and intention to use internet banking along with the influence of perceived benefits. This paper contributes by adding perceived risk with the original model adopted from Ajzen and Fishbein (1980). 


\section{Literature review}

Marketers have always attempted to explain consumer behavior for their success, and understanding consumer especially for technology based product and services is more complex than other product and services.

The TAM (Davis, 1989) represents an adaptation of the theory of reason action TRA, tailored to users' acceptance of information systems. It helps explain determinants of computer acceptance and can explicate user behaviors across a broad range of computing technologies

and populations; it is also parsimonious and theoretically justified (Davis et al., 1989)There has been a great deal of research on the Theory of Reasoned Action (Ajzen \&Fishbein, 1980; Sheppard, Hartwick, and Warshaw, 1988) Theory of Planned Behavior (Ajzen,1991) and Decomposed Theory of Planned Behaviour, (Taylor and Todd, 1995) .

The TAM (Davis, 1989) is also parsimonious and theoretically justified (Davis et al., 1989). The major determinants are perceived usefulness and ease of use (Figure 1).

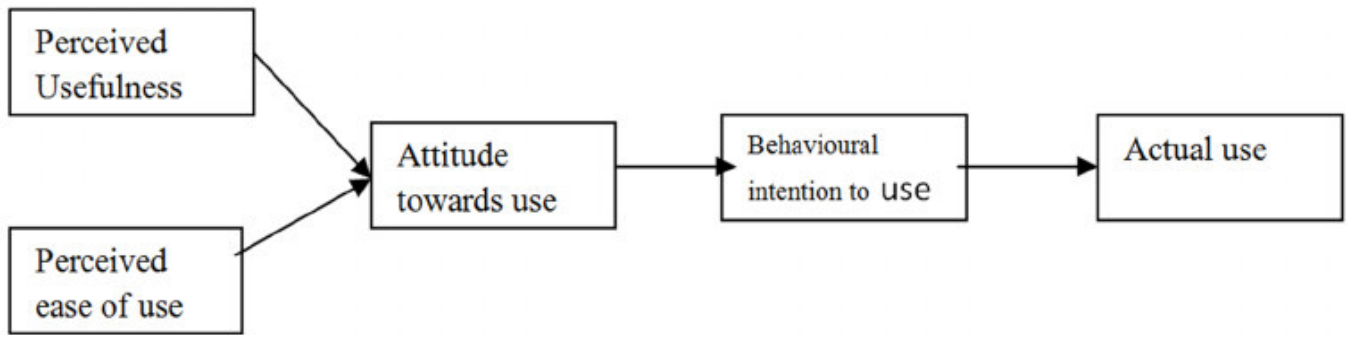

Fig 1: The Original Technology Acceptance Model TAM (Davis, 1989)

TAM is specifically tailored for modeling users' acceptance of information systems or technologies. The model suggests that when users are presented with a new technology, a number of factors influence their decision about how and when they will use it, notably Perceived usefulness (PU) and perceived ease of use (PEOU).Perceived usefulness (PU) and perceived ease of use (PEOU) are the two salient beliefs determining people's attitude towards accepting a technology(Davis 1989). Perceived usefulness has a stronger relationship with user acceptance of a technology, compared to perceived ease of use (Davis, 1989a). TAM theory has been changed a few times, leading to TAM2 (Venkatesh, 2000), Unified Theory of Acceptance and Use of Technology (UTAUT) (Venkatesh et al., 2003), or TAM 3 (Venkateshand,Bala, 2008). Each of these theories has donated greatly to the body of knowledge about technology acceptance.

Perceived Usefulness is defined by Fred Davis (1989) as the degree to which a person believes that using a particular system would enhance his or her job performance. The concept of perceived usefulness is based on a theoretical framework that includes the theory of self-efficacy, the theory of behavioral decision, the theory of expectations, and the theory of 'the diffusion of innovations', the theory of reasoned action and the theory of planned behavior (Baile, 2005). The theory of self-efficacy (Bandura, 1982) explains that individual behavior is influenced by the beliefs of expected result of this behavior. The concept of perceived usefulness is the equivalent here to this of the result's beliefs. The behavioral decision theory (Beach and Mitchell, 1978), concept of perceived usefulness as defined in the technology acceptance model of Davis (1989) seems to have as their primary origin the theory of reasoned action (Ajzen and Fishbein, 1980) and the theory of planned behavior (Ajzen, 1991) where the attitude toward the behavior corresponds, according to Baile (2005), to the perceived usefulness.

Perceived Ease of Use (PEOU) which is defined by Davis (1989) as the degree to which a person believes that using a particular system would enhance his job performance.It refers to the degree to which a person believes that using a particular system would be free of effort.The Technology Acceptance models suggest that perceived ease of use has a significant influence on perceived usefulness, behavior attitude, intention, and actual use (Davis, 1989). On the relation between perceived ease of use and perceived usefulness, Davis (1989) suggests that: "from a causal perspective, the regression results suggest that ease of use may be an antecedent of usefulness, rather than a parallel, direct determinant of usage".

Attitude (ATT) refers to an individual's positive or negative feelings (evaluative affect) about performing a particular behavior (Fishbein and Ajzen, 1975).According to them, attitude is a learned predisposition to respond in a consistently favorable or unfavorable manner with respect to a given object. Attitude researchers (Eagly and Chaiken 1993) generally agree that an evaluative response to an attitudinal object can be influenced by three types of input: by cognitive input (e.g., evaluation of candy bars may be affected by our belief that they taste sweet and chocolaty), by affective input (e.g., evaluation of the HSBC may be determined by positive or negative emotional experiences with HSBC banks) and by behavioral input (e.g., people's banking preferences maybe influenced by behavioral experiences, such as the kinds of foods they ate as children).

Perceived risk plays an important role of catalyst in many online financial transactions (Ndubisi and Sinti, 2006). If the customers find any difference in their actual buying experiences and buying goals, they will perceive higher risk and in turn that perceived risk would be dependent on the degree of subjective uncertainty of 
outcomes. In online services, the spatial and temporal separation between consumers and e - retailers and the unpredictability of the internet services generate an implicit uncertainty around on - line transactions (Al-Gahtani, 2011). The perceived risk associated with online transactions may reduce perceptions of behavioral and environmental control, and this lack of control is likely to negatively influence transaction intentions. However, consumers are likely to transact online if their risk perceptions about behavioral and environmental uncertainties are alleviated, so that they gain control over their online transactions (Kesharwani, and Bisht, 2012).Therefore, it is reasonable to infer that perceived risks has a negative influence on user attitude and intention to adopt Internet Banking,

\section{Objective}

Based on the theoretical model developed above, we formulate the research hypotheses as follows. As TAM is used as the base model, we need to test the following TAM hypotheses in the context of IB adoption.

H1: Attitude positively influences the intention to use Internet Banking.

$\mathrm{H} 2$ : Perceived usefulness positively influences the intention to use Internet Banking.

H3: Perceived usefulness positively influences attitudes towards the use of Internet Banking.

H4: Perceived ease of use positively influences attitudes towards the use of Internet Banking.

H5: Perceived ease of use positively influences the perceived usefulness of the use of Internet Banking.

H6: Perceived risk negatively influences attitudes towards the use of Internet Banking.

H7: Perceived risk negatively influences the intention to use Internet Banking.

Researcher will test the strength of the hypothesized relationships embedded in the theoretical model and the robustness of the model in predicting customers' intention to adopt online banking in the Bangladeshi business environment. The theoretical model is graphically presented in Fig. 2.

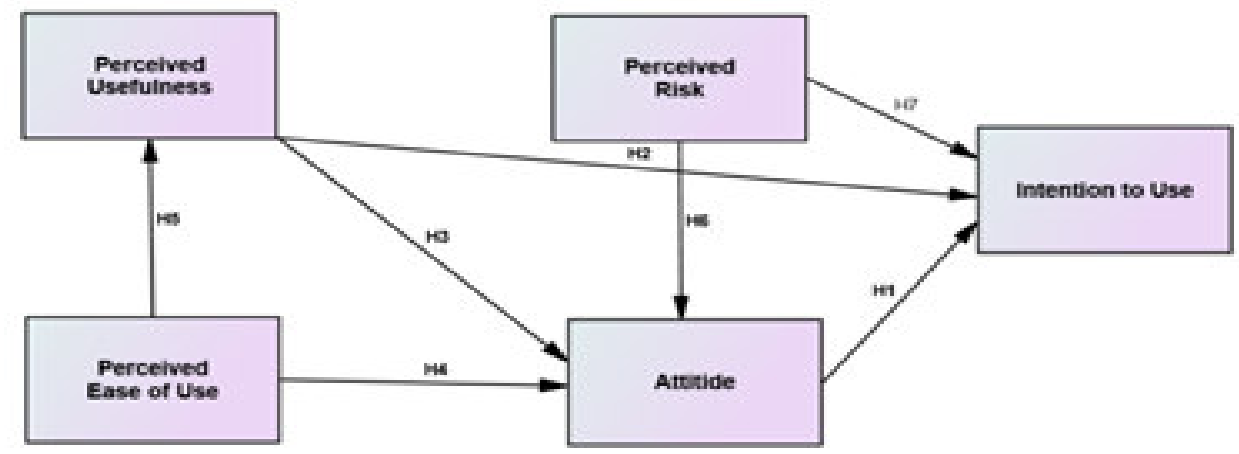

Figure 2: The proposed research model

\section{Research Method}

Cavana, Robert and Sekaran (2001) argued that to obtain the valid finding about the relationship between variables; researchers should develop planned procedure for gathering and interpreting data. To pursue the objectives of this study the researcher has followed a systematic Plan to collect, analyze and interpret data.

\subsection{Instrument Development}

The instrument was designed to include a two-part questionnaire; the first part includes nominal scales, and the remainder includes seven-point Likert scales, ranging from "Strongly disagree" (1) to "Strongly agree" (7). Accordingly, the first part is basic information. This part of questionnaire was used to collect basic information about respondents' characteristics including gender, age, education, occupation, experience and frequency of using online banking. The second part of questionnaire was developed based on the constructs of perceived usefulness, perceived ease of use, perceived risk, attitude, and intention to use.

The measurement instrument contained the scales from previous studies based on TAM, and perceived risk. One evident advantage of TAM scales is that these scales have been validated in e - commerce and online shopping contexts (Wang et al., 2003; McKechnie et al., 2006). The four items scales for perceived ease of use, perceived usefulness, and attitude were adapted from the measurements defined by Cheng et al. (2006) and Lai and $\mathrm{Li}$ (2005). Perceived risk and Intention to use were adapted from the measurements defined by $\mathrm{Chan}$ and $\mathrm{Lu}$ (2004), Cheng et al. (2006) and Lai and Li (2005), containing three items for each construct.

The constructs are defined in the following:

Perceived Ease of Use (PEOU) - defined by Davis (1989) as "the degree to which a person believes that using a particular system would enhance his job performance".

Perceived Usefulness (PU) - defined by Davis (1989) as "the degree to which a person believes that using a particular system would be free of effort". 
Perceived Risk (PR) - defined by Bauer (1960) as "the degree to which uncertainty and unfavorable consequences associated with consumers' expectation."

Attitude (ATT) - refers to an individual's positive or negative feelings (evaluative affect) about performing a particular behavior (Fishbein and Ajzen, 1975).

Intention to Use (INT)-refers to customers' intention to use, as opposed to their actual use of, IB services (Davis, 1989).

Before conducting the main survey, we performed a pre-test to validate the instrument. The pre-test involved 10 respondents who have more than 3 years experience using online banking. Respondents were asked to comment on the length of the instrument, the format, and the wording of the scales. Therefore, the instrument has confirmed content validity.

\subsection{Data Collection}

The population of interest is defined as current and potential users of Internet Banking in Bangladesh. In order to collect online banking users' information, convenient sampling was used to select the respondents from the commercial banks since it is easy to access clients. In e - commerce and other online services (including online shopping), internet banking is the most common payment mechanism. Our research design was deliberately aimed to capture perception of users to this common and most widely used payment gateway.

Users were free to participate at their own discretion. This survey, which yielded 468 responses, was conducted for one month, with incomplete responses and missing values deleted, resulting in a sample size of 389 users for an overall response rate of $83 \%$. Regarding estimation technique, if maximum likelihood estimation (MLE) is used, the sample size should be generally in the range of 200 to 400 (Malhotra and Dash, 2011). Sample demographics are depicted in Table 1. Seventy percent of the respondents were male and $29.6 \%$ were female. The majority of respondents $(52 \%)$ were over 30 years old. About $6.4 \%$ of the respondents did not have experience using online banking. Finally, the education levels of respondents were $37.3 \%$ college and $49.1 \%$ masters.

Table 1: Sample demographics

\begin{tabular}{|c|c|c|c|c|c|}
\hline Parameters & & Frequency & Percent & Valid Percent & Cumulative Percent \\
\hline \multirow{2}{*}{ Gender } & Male & 274 & 70.4 & 70.4 & 70.4 \\
\hline & Female & 115 & 29.6 & 29.6 & 100.0 \\
\hline \multirow{5}{*}{ Age(years) } & Under 19 & 24 & 6.2 & 6.2 & 6.2 \\
\hline & $20-29$ & 167 & 42.9 & 42.9 & 49.1 \\
\hline & $30-39$ & 98 & 25.2 & 25.2 & 74.3 \\
\hline & $40-49$ & 68 & 17.5 & 17.5 & 91.8 \\
\hline & 50 and above & 32 & 8.2 & 8.2 & 100.0 \\
\hline \multirow{6}{*}{ Occupation } & Student & 88 & 22.6 & 22.6 & 22.6 \\
\hline & Teacher & 65 & 16.7 & 16.7 & 39.3 \\
\hline & Banker & 91 & 23.4 & 23.4 & 62.7 \\
\hline & Govt. Officials & 39 & 10.0 & 10.0 & 72.8 \\
\hline & Private Service & 85 & 21.9 & 21.9 & 94.6 \\
\hline & Others & 21 & 5.4 & 5.4 & 100.0 \\
\hline \multirow{5}{*}{ Education } & High School & 42 & 1.8 & 1.8 & 10.8 \\
\hline & College/University & 145 & 37.3 & 37.3 & 48.1 \\
\hline & Masters & 191 & 49.1 & 49.1 & 97.2 \\
\hline & $\mathrm{PhD}$ & 5 & 1.3 & 1.3 & 98.5 \\
\hline & Others & 6 & 1.5 & 1.5 & 100.0 \\
\hline \multirow{2}{*}{ User Status } & Experienced & 364 & 93.6 & 93.6 & 93.6 \\
\hline & Non-experienced & 25 & 6.4 & 6.4 & 100.0 \\
\hline \multirow{5}{*}{ Years Using } & $<1$ year & 123 & 31.6 & 33.8 & 33.8 \\
\hline & $1-3$ year & 149 & 38.3 & 40.9 & 74.7 \\
\hline & 4-6 year & 74 & 19.0 & 20.3 & 95.1 \\
\hline & $>6$ year & 18 & 4.6 & 4.9 & 100.0 \\
\hline & Missing (No-exp.) & 9 & 6.4 & & \\
\hline \multirow{5}{*}{$\begin{array}{c}\text { Frequency } \\
\text { of Using }\end{array}$} & 1 time every day at least & 29 & 7.5 & 8.0 & 8.0 \\
\hline & 1 time every week at least & 188 & 48.3 & 51.6 & 59.6 \\
\hline & 1 time every month at least & 113 & 29.0 & 31.0 & 90.7 \\
\hline & 1 time every year at least & 34 & 8.7 & 9.3 & 100.0 \\
\hline & Missing (No-exp.) & 25 & 6.4 & & \\
\hline \multicolumn{2}{|r|}{ Total } & 389 & 100.0 & & \\
\hline
\end{tabular}




\section{Data Analysis}

In analyzing the collected data, The researcher followed the two-step procedure suggested by Anderson and Gerbing (1988). In this approach, both, measurement model and structural models are evaluated separately. First,the researcher examined the measurement model to measure reliability and validity, then, we examined the structural model to investigate the strength and direction of the relationships among the theoretical constructs. A confirmatory factor analysis (CFA) was done by using statistical software SPSS AMOS 22.0.

\subsection{Analysis of Measurement Model}

Researcher evaluated the measurement scales using the three criteria suggested by Fornell and Larcker (1981).

(1) All indicator factor loading ( $\mathrm{k}$ ) should be significant and exceed 0.5 .

(2) Construct reliabilities should exceed 0.8 .

(3) Average variance extracted (AVE) by each construct should exceed the variance due to measurement error for the construct (e.g. AVE should exceed 0.5).

Here, all $(\mathrm{k})$ values in confirmatory factor analysis of the measurement model exceeded 0.5 and were significant at $p=0.001$. Composite reliabilities (CR) of constructs ranged from 0.845 to 0.907 (see Table 3) and Average Variance Extracted (AVE), ranging from 0.644 to 0.731 means all three conditions for convergent validity was met. Cranach's alpha scores shown in Table 2 indicated that each construct exhibited strong internal reliability.

Table 2: Construct Reliability and convergent validity

\begin{tabular}{|c|c|c|c|c|c|}
\hline Construct/Indicator & Item & $\begin{array}{l}\text { Factor } \\
\text { loading }\end{array}$ & $\begin{array}{l}\text { Composite } \\
\text { reliability (CR) }\end{array}$ & $\begin{array}{l}\text { Average varience } \\
\text { extracted (AVE) }\end{array}$ & $\begin{array}{l}\text { Cronbach's } \\
\text { alpha }\end{array}$ \\
\hline Perceived usefulness & pu1 & 0.869 & \multirow[t]{4}{*}{0.907} & \multirow[t]{4}{*}{0.710} & \multirow[t]{4}{*}{0.897} \\
\hline & pu2 & 0.785 & & & \\
\hline & pu3 & 0.846 & & & \\
\hline & pu4 & 0.870 & & & \\
\hline \multirow[t]{4}{*}{$\begin{array}{lll}\begin{array}{l}\text { Perceived ease of } \\
\text { use }\end{array} & \\
\end{array}$} & peoul & 0.853 & \multirow[t]{4}{*}{0.905} & \multirow[t]{4}{*}{0.708} & \multirow[t]{4}{*}{0.893} \\
\hline & peou2 & 0.837 & & & \\
\hline & peou3 & 0.848 & & & \\
\hline & peou4 & 0.835 & & & \\
\hline \multirow[t]{4}{*}{ Perceived risk } & pr1 & 0.797 & \multirow[t]{4}{*}{0.892} & \multirow[t]{4}{*}{0.674} & \multirow[t]{4}{*}{0.897} \\
\hline & pr2 & 0.817 & & & \\
\hline & pr3 & 0.844 & & & \\
\hline & pr4 & 0.824 & & & \\
\hline \multirow[t]{4}{*}{ Attitude } & att1 & 0.844 & \multirow[t]{4}{*}{0.903} & \multirow[t]{4}{*}{0.700} & \multirow[t]{4}{*}{0.902} \\
\hline & att2 & 0.864 & & & \\
\hline & att3 & 0.785 & & & \\
\hline & att4 & 0.851 & & & \\
\hline \multirow[t]{3}{*}{ Intention } & int1 & 0.824 & \multirow[t]{3}{*}{0.891} & \multirow[t]{3}{*}{0.731} & \multirow[t]{3}{*}{0.882} \\
\hline & int 2 & 0.824 & & & \\
\hline & int3 & 0.889 & & & \\
\hline
\end{tabular}

\subsection{Multicollinearity}

To determine whether any multicollinearity effects existed, researcher has checked whether there was any warning message produced by the AMOS output that signaled a problem of multicollinearity. The results showed that there was no evidence of multicollinearity. The potential problem of multicollinearity can be further examined formally in the context of regression analysis. The variance inflation factor (VIF), which indicates the degree to which each predictor variable is explained by other predictor variables, is a common measure of multicollinearity in regression analysis (Hair et al., 1998). A threshold VIF that is less than or equal to 10 (i.e. tolerance $>0.1$ ) is commonly suggested (Hair et al., 1998). The VIFs for PU, PEOU and attitude were 3.76, 4.37, and 3.19 , respectively, in predicting intention, providing further evidence against multicollinearity.

\subsection{Analysis of the structural model}

Researcher has used the hypothesized model to test model fitness by performing a Confirmatory Factor Analysis (CFA) on the data. The results show that the hypothesized model is recursive, i.e., uni-directional (Table 2). There were 190 distinct sample moments (i.e., pieces of information) from which to compute the estimates of the default model, and 47 distinct parameters to be estimated, leaving 143 degrees of freedom. The minimum iteration was achieved, thereby providing an assurance that the estimation process yielded an admissible solution, 
eliminating any concern about multicollinearity effects.

Table 3: Model Fit Summary:

\begin{tabular}{|c|c|c|}
\hline Indexes & $\begin{array}{l}\text { Obtained } \\
\text { Values }\end{array}$ & Suggested Values \\
\hline Chi-square & 264.931 & \\
\hline Goodness of fit index (GFI) & 0.939 & \multirow{5}{*}{$\begin{array}{l}\text { Fit statistics greater than or equal to } 0.9 \text { for GFI, NFI, RFI, and } \\
\text { CFI indicate a good model fit (Bagozzi et al., 1991; Hair et al., } \\
\text { 1998) }\end{array}$} \\
\hline Comparative fit index (CFI) & 0.981 & \\
\hline $\begin{array}{l}\text { Adjusted goodness of fit index } \\
\text { (AGFI) }\end{array}$ & 0.919 & \\
\hline Normed fit index (NFI) & 0.960 & \\
\hline Relative fit index (RFI) & 0.952 & \\
\hline $\begin{array}{l}\text { Root mean square error of } \\
\text { approximation (RMSEA) }\end{array}$ & 0.046 & 0.05 to 0.08 are acceptable (Hair et al., 1998) \\
\hline CMIN/DF & 1.853 & $<5.0$ (Wheaton et al., 1977) \\
\hline
\end{tabular}

The researcher assessed the overall goodness-of-fit using the chi-square test. The chi-square test assesses the adequacy of a hypothesized model in terms of its ability to reflect variance and covariance of the data. In our analysis, the $\chi^{2}$ value $(264.931)$, together with its degrees of freedom $(190)$ and probability value $(p<0.0005)$, a finding usual with large sample sizes (Doney and Cannon, 1997). Due to its tendency to be sensitive to sample size, other fit indices (e.g., GFI, AGFI, CFI, NFI, and RFI) were considered in conjunction with the chi-square. For the statistical significance of parameter estimates, $t$ values were used. The results of structural equation modeling obtained for the proposed conceptual model revealed a ratio of chi-square to the degree of freedom $\left(\chi^{2} / \mathrm{df}\right)$ of $1.853(\mathrm{p}<0.005)$.

Another test statistic is the Critical Ratio (C.R.), which represents the parameter estimate divided by its standard error (S.E.). As a "rule of thumb", the C.R. needs to be 1.96 if the estimate is acceptable (Chau, 1997; Hair et al., 1998). The results showed that all C.R. values were larger than 1.96, indicating that they were all acceptable (Table 4). Other fit statistics are shown in Table 3 with their threshold level.

\subsection{Hypotheses testing}

A structural equation modeling (SEM) approach was adopted in our data analysis (Bagozzi et al., 1991). Fig. 2 presents the results of the structural model with significant paths, and the standardized path coefficients between constructs. Intention to use Internet banking in this study was jointly predicted by perceived usefulness $(b=$ 0.241 , Standardized path coefficient, $p<0.05)$, perceived risk $(b=-0.421, p<0.001)$, attitude $(b=0.189, p<$ $0.05)$ and these variables together explained $58 \%$ of the variance of intention to use $\left(\mathrm{R}^{2}=0.58\right.$, coefficient of determination). As a result, Hypotheses 1, 2, and 7 were all supported. Attitude was predicted by perceived usefulness $(b=0.293, p<0.01)$, perceived ease of use $(b=0.402, p<0.05)$, and perceived risk $(b=-0.197, p<$ 0.05). Together these variables explained $79 \%$ of the total variance. These findings validated Hypotheses 3,4 , and 6 respectively. Perceived ease of use $(b=1.029, p<0.001)$ significantly influenced perceived usefulness and explained $83 \%$ of the total variance in PU. As a result, Hypotheses 5 were supported. Our hypotheses results are shown in Fig. 2.

The level of PEOU and PR had significant indirect effects on intention to use online banking, suggesting the important mediating effects of PU and attitude. To further assess the significance of indirect effects of predictor variables on intentions to use online banking, a decomposition of the effects analysis was conducted (see Table 5). 
Table 4: Unstandardized and standardized estimates

\begin{tabular}{|c|c|c|c|c|c|c|c|c|c|c|}
\hline \multicolumn{7}{|c|}{ Unstandardized Estimate } & \multicolumn{4}{|c|}{ Standardized Estimate } \\
\hline & & & Estimate & S.E. & C.R. & $\mathrm{P}$ & & & & Estimate \\
\hline PU & $\begin{array}{ll}<--- \\
\end{array}$ & PEOU & 1.029 & .052 & 19.926 & $* * *$ & $\mathrm{PU}$ & $\mid<---$ & PEOU & 0.912 \\
\hline ATT & $<---$ & PEOU & 0.402 & .155 & 2.597 & $* *$ & ATT & $<---$ & PEOU & 0.394 \\
\hline ATT & $<---$ & PU & 0.293 & .095 & 3.079 & $* *$ & ATT & $<---$ & PU & 0.324 \\
\hline ATT & $<---$ & PR & -0.197 & .093 & -2.114 & $*$ & ATT & $<---$ & PR & -0.205 \\
\hline INT & $<---$ & ATT & 0.189 & .113 & 1.666 & $*$ & INT & $<---$ & ATT & 0.170 \\
\hline INT & $<---$ & PR & -0.421 & .101 & -0.417 & $* * *$ & INT & $<---$ & PR & -0.395 \\
\hline INT & $<---$ & PU & 0.241 & .101 & 2.401 & $*$ & INT & $<--$ & PU & 0.240 \\
\hline pu1 & $<---$ & $\mathrm{PU}$ & 0.938 & .040 & 23.597 & $* * *$ & pu1 & $<--$ & PU & 0.869 \\
\hline pu2 & $<---$ & $\mathrm{PU}$ & 0.862 & .044 & 19.654 & $* * *$ & pu2 & $<---$ & PU & 0.785 \\
\hline pu3 & $<---$ & $\mathrm{PU}$ & 0.891 & .040 & 22.244 & $* * *$ & pu3 & $<---$ & PU & 0.846 \\
\hline pu4 & $<---$ & $\mathrm{PU}$ & 1.000 & & & & pu4 & $<---$ & PU & 0.872 \\
\hline peoul & $<---$ & PEOU & 1.000 & & & & peou1 & <--- & PEOU & 0.853 \\
\hline peou2 & <--- & PEOU & 0.995 & .046 & 21.454 & $* * *$ & peou2 & $<---$ & PEOU & 0.837 \\
\hline peou3 & $<---$ & PEOU & 0.921 & .042 & 21.932 & $* * *$ & peou3 & $<---$ & PEOU & 0.849 \\
\hline peou4 & <--- & PEOU & 0.989 & .047 & 21.273 & $* * *$ & peou4 & $<---$ & PEOU & 0.834 \\
\hline pr1 & \begin{tabular}{|l|}
$<--$ \\
\end{tabular} & PR & 0.902 & .050 & 18.038 & $* * *$ & pr1 & $\mid<---$ & PR & 0.797 \\
\hline pr2 & $<---$ & PR & 1.000 & & & & pr2 & $<--$ & PR & 0.817 \\
\hline pr3 & $<---$ & PR & 0.880 & .045 & 19.377 & $* * *$ & pr3 & $<--$ & PR & 0.844 \\
\hline pr4 & $<---$ & PR & 0.922 & .049 & \begin{tabular}{|l|}
18.690 \\
\end{tabular} & $* * *$ & pr4 & $<--$ & PR & 0.824 \\
\hline att1 & $<---$ & ATT & 0.964 & .045 & 21.233 & $* * *$ & att1 & $<--$ & ATT & 0.844 \\
\hline att2 & $<---$ & ATT & 0.961 & .044 & \begin{tabular}{|l|}
22.039 \\
\end{tabular} & $* * *$ & att2 & $<--$ & ATT & 0.863 \\
\hline att3 & $<---$ & ATT & 0.878 & .046 & \begin{tabular}{|l|}
18.962 \\
\end{tabular} & $* * *$ & att3 & $<---$ & ATT & 0.787 \\
\hline att4 & $<---$ & ATT & 1.000 & & & & att4 & $<--$ & ATT & 0.851 \\
\hline int1 & $<---$ & INT & 1.000 & & & & int1 & $<---$ & INT & 0.852 \\
\hline int2 & $<---$ & INT & 0.957 & .048 & \begin{tabular}{|l|}
19.763 \\
\end{tabular} & $* * *$ & int2 & $<--$ & INT & 0.823 \\
\hline int3 & $<---$ & INT & 0.992 & .045 & 21.875 & $* * *$ & int3 & $<---$ & INT & 0.888 \\
\hline
\end{tabular}

* $\quad$ Significant at $\mathrm{P}<0.05$

** Significant at $\mathrm{P}<0.01$

$* * *$ Significant at $\mathrm{P}<0.001$

Table 5: Direct, indirect and total effects - estimates

\begin{tabular}{|c|c|c|c|c|c|c|}
\hline \multirow{2}{*}{ Criterion variable predictors } & \multicolumn{3}{|c|}{ Attitude } & \multicolumn{3}{c|}{ Intention to use } \\
\cline { 2 - 7 } & $\begin{array}{c}\text { Direct } \\
\text { effects }\end{array}$ & $\begin{array}{c}\text { Indirect } \\
\text { effects }\end{array}$ & $\begin{array}{c}\text { Total } \\
\text { effects }\end{array}$ & $\begin{array}{c}\text { Direct } \\
\text { Effects }\end{array}$ & $\begin{array}{c}\text { Indirect } \\
\text { effects }\end{array}$ & $\begin{array}{c}\text { Total } \\
\text { effects }\end{array}$ \\
\hline Perceived ease of use & $\mathbf{0 . 3 9 4}$ & $\mathbf{0 . 2 9 6}$ & $\mathbf{0 . 6 9 0}$ & -- & $\mathbf{0 . 3 3 6}$ & $\mathbf{0 . 3 3 6}$ \\
\hline Perceived usefulness & $\mathbf{0 . 3 2 4}$ & -- & $\mathbf{0 . 3 2 4}$ & $\mathbf{0 . 2 4 0}$ & $\mathbf{0 . 0 5 5}$ & $\mathbf{0 . 2 9 5}$ \\
\hline Perceived risk & $\mathbf{- 0 . 2 0 5}$ & -- & $\mathbf{- 0 . 2 0 5}$ & $\mathbf{- 0 . 3 9 9}$ & $\mathbf{- 0 . 0 3 5}$ & $\mathbf{- 0 . 4 3 4}$ \\
\hline Attitude & -- & -- & -- & $\mathbf{0 . 1 7 0}$ & -- & $\mathbf{0 . 1 7 0}$ \\
\hline
\end{tabular}




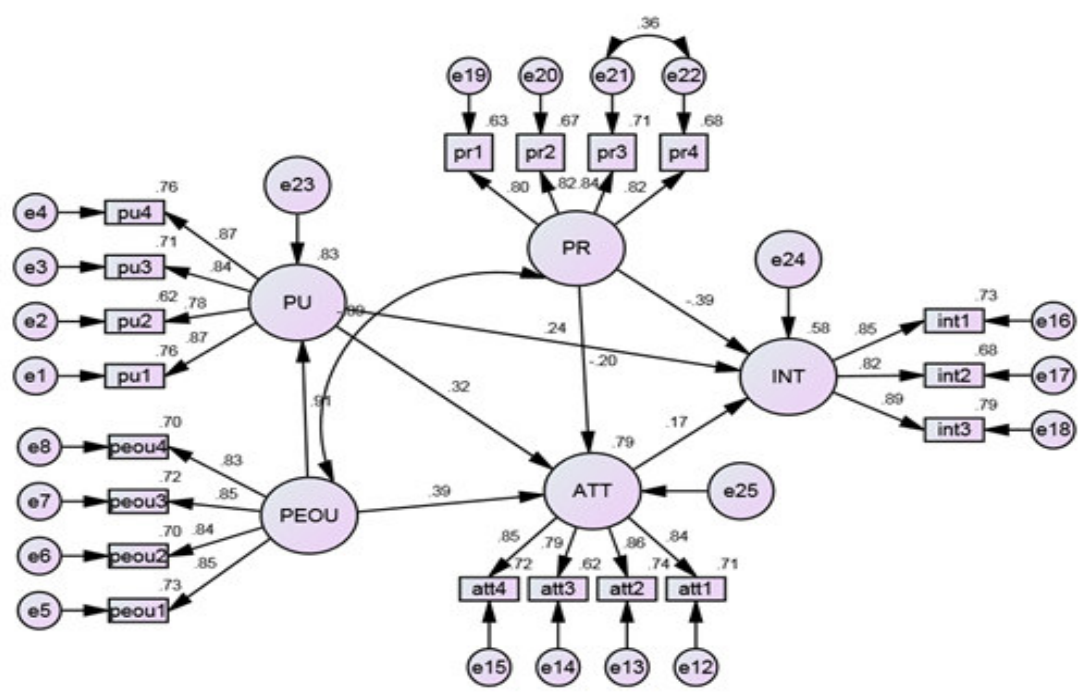

Figure 3: Result of structural modeling analysis

\section{Conclusion:}

It can be easily infer that incorporation of technology is very important for the development and change of the society. But the sheer success depends on the users who have to accept and adopt such radical technologies. In Bangladesh online banking has opened up new windows of opportunity for both the banks and consumers. Since its a new technology among the consumers, it will take sometime to be fully accepted .One important issue is the perceived risks associated with online banking that must be lowered to speed up its adaption quickly. some of the major risk of e-banking included operational risks (e.g. security risks, system design, implementation and maintenance risks); customer misuse of products and services risks; legal risks etc. Findings of the paper confirms that Perceived ease of use, Perceived usefulness positively influence the intention and attitude to use Internet Banking and Perceived risks negatively affects both. Form the research findings it is also evident that the level of PEOU and PB had significant indirect effects on intention to use online banking. These finding will help both the researcher and practitioners in understanding the behavior pattern of online banking service users. For future research more variables like received benefits of online banking can be include separately or along with perceived risk to further extend the technology acceptance model. This variables can also be incorporated to explain consumer behavior for other technology based product and services.

\section{References}

Ajzen I., \& Et Fisbein M. (1980).Understanding Attitudes and Predicting Social Behavior, Prentice Hall : Englewood Cliffs, NY 2

Ajzen I.(1991),The Theory of Planned Behavior. Organizational Behavior and Human Decision Processes, Vol. 50

Al - Gahtani, S.S. (2011).Modeling the electronic transactions acceptance using extended technology acceptance model. Applied Computing and Informatics, Vol. 9, pp. 47 - 77

Ankit ,Kesharwani.,\& Shailendra, Singh.Bisht. (2012). The impact of trust and perceived risk on internet banking adoption in India: An extension of technology acceptance model. International Journal of Bank Marketing, Vol. 30 Iss: 4, pp.303 - 322

Bauer, R.A. (1960). Consumer Behavior as Risk Taking. Risk Taking and Information Handling in Consumer Behavior.Boston University Press, Boston. MA, pp. 23 - 33

Bagozzi, RP.,Yi ,Y.,\& Phillips, LW.(1991). Assessing construct validity in organizational research. Admin Sci Quarts 1991;36 (3):421-30

Bruene J .(2002). Online banking by the numbers[Online]. Available:http://www.onlinebankingreport.com.

Blair H. Sheppard, Jon, Hartwick., \& Paul R. Warshaw.(1988). The Theory of Reasoned Action: A MetaAnalysis of Past Research with Recommendations for Modifications and Future Research.Journal of Consumer Research, Volume 15, Issue 3, 1 December 1988

Baile S., (2005). L'approchecomportementale de l'évaluation des systèmesd'information: théoriesettaxonomie des modèles de recherche

Bandura A., (1982). Self-EfficacyMechanism in Human Agency. American Psychologist, Vol.37, n², p.122-147

Beach, L. R. \& Mitchell, T. R. (1978). A contingency model for the selection of decision strategies. Academy of Management Review, 3, 439-449. 
Bauer, R.A. (1960). Consumer Behavior as Risk Taking. In: Hancock, R.S., Ed., Dynamic Marketing for a Changing World. Proceedings of the 43rd. Conference of the American Marketing Association, 389-398.

Chan, S.C.\& Lu, M.T. (2004). Understanding internet banking adoption and usage behavior: a Hong Kong perspective. Journal of Global Information Management, Vol. 12 No. 3, pp. 21 - 43.

Cheng, T., Lama, D., \& Yeung, A. (2006). Adoption of internet banking: an empirical study in Hong Kong. Decision Support Systems, Vol. 42 No. 3, pp. 1558 - 72

Chau, P. Y. K. (1997). Reexamining a model for evaluating information center success using a structural equation modeling approach. Decision Sciences, 28, 309-335

Cavana, Robert Y., Delahaye, Brian L., \& Sekaran,Uma. (2001). Applied Business research: Qualitative and Quantitative Methods. John Wiley \& Sons Inc, Milton, Queensland.

Chowdhury, S. K.,\& Salam, M. (2015).Predicting Attitude Based on Cognitive, Affective and Conative Components: An Online Shopping Perspective. Stamford Journal of Business Studies, Stamford University Bangladesh, Volume 6/7, Issue II/I, pp101-115,ISSN 1817-1680

Davis, F. D. (1989). Perceived usefulness, perceived ease of use, and user acceptance ofinformation technology. MIS Quarterly, 13, 319-336.

Doney, P.M., \& Cannon, J.P. (1997). An Examination of the nature of trust in buyer-seller relationships. Journal of Marketing, 61, 2, 35-51

Davis, F.D, Bagozzi, P. R. ,\&Warshaw P. (1989).User acceptance of computer technology: A comparison of two theoretical models.Management Science, 35982 - 1003.

Eagly, A. H., \&Chaiken, S.(1993).The psychology of attitudes. Fort Worth, TX: Harcourt Brace Jovanovich.

.Fishbein M., Ajzen I. (1975). Belief, attitude, intention, and behavior: An introduction to theory and research. Reading, MA: Addison-Wesley.

Fornell, C.\& Larcker, DF.(1981). Evaluating structural equation models with unobservable variables and measurement error. J Marketing Res18(1):39-47.

Hair JF et al.(1998). Multivariate data analysis, Upper Saddle River, NJ: Prentice-Hall.

Kamel S. (2005). The use of information technology to transform the banking sector in developing nations. Inf. Tech. Dev. 11(4): 305-312.

Lai V.S., \&Li, H.(2005).Technology acceptance model for internet banking: an invariance analysis. Inform Manage 42(2):373-86.

Lai P. C .(2006). The significant of E-business and knowledge-based Customer Relationship inthe E-market Place Environment. INTI Journal, 2 (1) 552-559.

Lai, P. C. (2007). The Chip Technology Management Implication in the Era of Globalization: Malaysian Consumers' Perspective. Asia Pacific Business Review, 3(1), 91-96

Lai P. C. (2010). E-business and E-banking. Japan Society for Software Science and Technology. Itech research group.

Lai, P. C. (2016). Design and Security impact on consumers' intention to use single platform Epayment.Interdisciplinary Information Sciences, 22 (1), 111-122

Lovelock, C. (2001). Services Marketing, People, Technology, Strategy.Prentice Hall, New Jersey.

Lee, Ming-Chi. (2009). Factors influencing the adoption of internet banking: An integration of TAM and TPB with perceived risk and perceived benefit. Electronic commerce research and applications 8.3 130-141.

McKechnie, S., Winklhofer, H., \& Anew, C. (2006).Applying the technology acceptance model to the online retailing of financial services. International Journal of Retail \& Distribution Management, Vol. 34 Nos 4/5, pp. $388-410$.

Malhotra, N., \& Dash, S. (2011). Marketing research: An applied orientation. (6th ed.),Dorling Kindersley (India)Pvt, Ltd.

Nath, R., Shrick, P., Parzinger, M. (2001). Bankers perspectives on Internet banking. e-Service Jour. Indiana University Press.

Ndubisi, N.O. and Sinti, Q. (2006), Consumer attitudes, system's characteristics and internet banking adoption in Malaysia, Marketing Research News, Vol. 29 Nos 1/2, pp. 16 - 27.

Pikkarainen, T., Pikkarainen, K., Karjaluoto, H., \&Pahnila, S. (2004). Consumer acceptance of online banking:An extension of the technology acceptance model. Internet Research, 14(3), 224-235.

Venkatesh, V.( 2000). Determinants of perceived ease of use: Integrating control, intrinsicmotivation, and emotion into the technology acceptance model. Inf. Syst. Res. 11 (4),342-365.

Venkatesh, V., Bala, H. (2008). Technology acceptance model 3 and a research agenda on interventions. Decis. Sci. 39 (2), 273-315.

Wang, Y.S., Wang, Y.M., Lin, H.H. and Tang, T. (2003), Determinants of user acceptance of internet banking.International Journal of Service Industry Management, Vol. 14 No. 5, pp. 501 - 19

Wheaton, B., Muthen, B., Alwin, D.F.\& Summers, G.F.(1977). Assessing reliability and stability in panel models, Sociological Methodology, 8, 84-13 